\title{
A DEBRECENI SZENNYVÍZTISZTÍTó TELEP VIZSGÁLATA KÜLÖNÖS TEKINTETTEL A FERMENTÁCIÓS FOLYAMAT MEGBÍZHATÓ ÉRTÉKELÉSÉRE ALKALMAZHATÓ FOS/TAC ARÁNY NYOMON KÖVETÉSÉVEL
}

\section{EXAMINATION OF DEBRECEN WWTP FOCUSING ON THE FOS/TAC RATIO AS A RELIABLE ASSESSMENT PARAMETER USED FOR THE FERMENTATION PROCESS}

\author{
Truzsi Alexandra $^{1}$, Bodnár Ildikó ${ }^{2}$, Fülöp Zoltán ${ }^{3}$ \\ ${ }^{1,2}$ Debreceni Egyetem Müszaki Kar, Környezet- és Vegyészmérnöki Tanszék \\ Cím: 4028 Magyarország, Debrecen, Ótemetö utca, 2-4. \\ lalexandra.truzsi@gmail.com²bodnari@eng.unideb.hu \\ ${ }^{3}$ Debreceni Vizmü Zrt., Szennyvíztisztitó Üzem, Cím: 4002 Magyarország, Debrecen, \\ Vértesi út 1-3.fulop.zoltan@debreceni-vizmu.hu
}

\begin{abstract}
The anaerobic digestion is a widely used economical method for sewage sludge stabilization and also purification of waste water with a high organic content. All effective anaerobic digesters transform the organic matter into biogas containing methane, which usable component covers a significant share of the heat and electricity consumption of the wastewater treatment plant (WWTP). The increasing amount of biogas is a priority task of WWTPs, which we can achieve a deeper knowledge of anaerobic digestion processes. The main task of this study is the optimization of anaerobic sludge treatment of Debrecen WWTP. Digester towers processes and their impact on the biogas yield were also priority studied.
\end{abstract}

Keywords: anaerobic sludge digestion, biogas yield, FOS/TAC ratio

\section{Összefoglalás}

A szennyvíziszap kezelésének egyik gazdaságos módja az anaerob lebontás, melyet széles körben alkalmaznak szennyvíziszapok stabilizálására és nagy szerves anyag tartalmú szennyvizek tisztítására is [1]. Minden jól müködő anaerob fermentor megegyezik abban, hogy benne a szerves anyag átalakul metán tartalmú biogázzá, amely fedezi többek között a szennyvíztisztító telep hö- és villamosenergiafogyasztásának jelentős részét. A biogáz mennyiségének növelése kiemelt feladat, melyet az anaerob lebontás folyamatainak alapos megismerésével érhetünk el [2]. Jelen tanulmány célja a Debreceni Vízmü Zrt. Szennyvíztisztító Üzemében az anaerob szennyvíziszap kezelésének optimalizálása. Kutatómunkánkban kiemelten vizsgáltuk a rothasztó tornyokban lejátszódó folyamatokat, s azok hatását a biogáz kihozatalra, minőségre.

Kulcsszavak: anaerob iszaprothasztás, biogáz hozam, FOS/TAC arány

\section{Bevezetés}

A szennyvíztisztító telepek üzemeltetése szempontjából fontos, hogy az anaerob rot- hasztási folyamatokat minden esetben megfelelő módon ellenőrizzük, az információk birtokában az üzemmenetbe beavatkozzunk és ezzel stabil müködést biztosítsunk a 
technológiai folyamat számára [3]. Kutatómunkánk során célunk volt, hogy olyan vizsgálatokat alkalmazzunk, amelyekkel az anaerob fermentorokban lejátszódó folyamatok az eddigieknél jobban jellemezhetöek. Célunk volt továbbá, hogy az üzemeltetés számára a kellő információval szolgáló vizsgálati módszereket, az üzemi laboratórium rendszeres vizsgálatai közé is beépíthessük.

\section{Szakirodalmi áttekintés}

A szennyvíztisztító telepeken működő iszaprothasztókban lejátszódó folyamatok ellenőrzésére több paraméter áll rendelkezésre ilyen a pH, a szárazanyag- és szervesanyag-tartalom, az illósav, a lúgosság, az illósav/lúgosság aránya, a gázmenynyiség és gázösszetétel mérése [4]. Az illósav/lúgosság aránya (FOS/TAC arány), mint ellenőrzö paraméter a fermentáció állapotát jellemzi, amely a két mért paraméterből számítható [5].

\section{Anyag és módszer}

A kutatáshoz kapcsolódó méréseket a Debreceni Vízmủ Zrt. Szennyvíztisztító Üzem telepi laboratóriumában végeztük, ahol lehetőségünk nyílt a szennyvíziszap minták analitikai célú vizsgálatára. A mintavétel a telepen lévő üzemi rothasztókból a reggeli órákban történt. Az illósav és lúgosság értékek meghatározásához szükséges 1 liter mennyiségü iszapmintákat napi rendszerességgel az iszaprothasztó tornyok mintavevő csövének végén, 3-4 perccel a leengedés kezdetét követően vettük, azért hogy a csőrendszerben lévő iszap a mintavétel elött kiürüljön.

\section{Eredmények és értékelésük}

\subsection{Az illósav és a lúgosság koncent- rációk összefüggésének vizsgálata}

A szakirodalmak szerint a házi szennyvíziszappal müködő rothasztóban a $\mathrm{CaCO}_{3}$ ban kifejezett lúgosság optimális értéke
2000-3500 mg/l körüli. A lúgosság egy puffer kapacitás, amely a betáplált anyag minőségén, összetételén múlik. Ha optimális a beadagolt anyag összetétele a lúgosság értéke állandó és stabil lesz. A lúgosság csökkenését eredményezheti, ha a rendszerben lévő ammónium-ion koncentráció csökken, vagy az illósavak mennyisége emelkedik. Növekedést idézhet elö, ha növeljük a bejuttatott ammónium-ion koncentrációját, vagy az illósav koncentrációja csökken [4].

$\mathrm{Az}$ illósav és a lúgosság értékek összefüggésének vizsgálata során a kapott eredményekből arra lehet következtetni, hogy az összes lúgosságra vonatkozó értékek nem csökkentek $3000 \mathrm{mg} / \mathrm{l}$ alá. Az anaerob rothasztás biológiai folyamatai optimálisan müködtek, vagyis a vizsgált iszapminták betáplálásának mennyisége megfelelő volt a kísérleti időszakban. A lúgosság eredmények mellett az illó (zsír)savak megfelelő koncentrációban voltak jelen, ezáltal a metántermelés folyamata is stabilan müködött. A savtermelő fázisban keletkező illósav $1500 \mathrm{mg}_{\text {ecetsav }} / \mathrm{dm}^{3}$ koncentráció felett gátolhatja a metántermelés folyamatát, mely a telep esetében is megállapítható volt a vizsgált időszakhoz kötődő augusztus hónap közepén. A szakirodalmi értékekkel összehasonlítva a rothasztó tornyokban mérhető illósavak koncentrációi a vizsgálati időszakban nem lépték túl a kritikus értéket (2000-3000 mg/l) ezáltal a rothasztó működése megfelelönek tekinthetö.

\subsection{A FOS/TAC arány meghatározása}

Az anaerob fermentációs folyamat stabilitásának további ellenőrzésére a FOS/TAC módszert (Nordmann, 1977) alkalmaztuk [6]. A módszer lehetővé teszi a folyamat problémáinak, kritikus állapotának elörejelzését. Az illósav és lúgosság érték aránya meghatározza a savkoncentráció és a puffer-kapacitás hányadosát a fermentációs tápoldatban [7]. A FOS az illékony szerves savak rövidítése, amit $\mathrm{mg}$ ecetsav- 

folyamat megbizható értékelésére alkalmazható FOS/TAC arány nyomon követésével

egyenérték $/ \mathrm{dm}^{3}$-ben mérnek, míg a TAC az összes szervetlen szén (a bázisos pufferkapacitás) rövidítése, amit $\mathrm{mg} \mathrm{CaCO}_{3} / \mathrm{dm}^{3}$ ben mérnek [8]. A 0,1 és 0,2 között detektált FOS/TAC arány eredmények esetén tisztán szennyvíziszap rothasztás történt, emellett a zsírbeszállítás minden hónapban egyenletes volt. Augusztus 22-23-án jelentős csapadék (több mint $60 \mathrm{~mm}$ ) esett a két nap alatt, illetve a tisztított szennyvíz menynyisége is több volt, mint $62.000 \mathrm{~m}^{3}$ (több, mint 55\%-os többlet) augusztus 22-én. Ezen kívül ebben az időszakban váltott a telep a VIRON Plus 40-röl vas(III)-kloridra, így az átállás, illetve az új vegyszer más összetétele is hozzájárulhatott a kapott eredményekhez.

A rothasztó tornyokra is több iszap került feladásra, és a tartózkodási idő is 25 nap volt ebben az időszakban. Ez is eredményezhette a 0,1 körüli FOS/TAC arányokat, melyek végig együtt mozogtak a toronyra feladott iszap szervesanyagtartalmával. A FOS/TAC arány 0,14 és 0,3 között változott, átlagos értéke $0,2 \pm 0,05$ volt, mely a tapasztalati szabály szerint alacsony biomassza bevitelt jelent [4].

\subsection{A pH, szén-dioxid tartalom és a FOS/TAC összefüggésének vizsgá- lata}

A pH, szén-dioxid tartalom és a FOS/TAC paraméterekre vonatkozó mérési eredményeket és ezek összefüggését az $\mathbf{1}$. ábrán foglaltuk össze. A grafikonon a $\mathrm{pH}$ változás akkor kezdődött el, amikor az aránypár 0,1-hez kezdett közelíteni. Ez a változás a $\mathrm{CO} 2$ esetében még szembetünőbb, hiszen ahogy állandósult a 0,1 körüli FOS/TAC arány a szén-dioxid mennyisége emelkedni kezdett.

Ebből arra tudtunk következtetni, hogy szeptember végén kedvezőtlen irányba mozdult el a gáztermelődési folyamat, melyre a kismértékben megnövekedett illósav koncentráció is utalt.

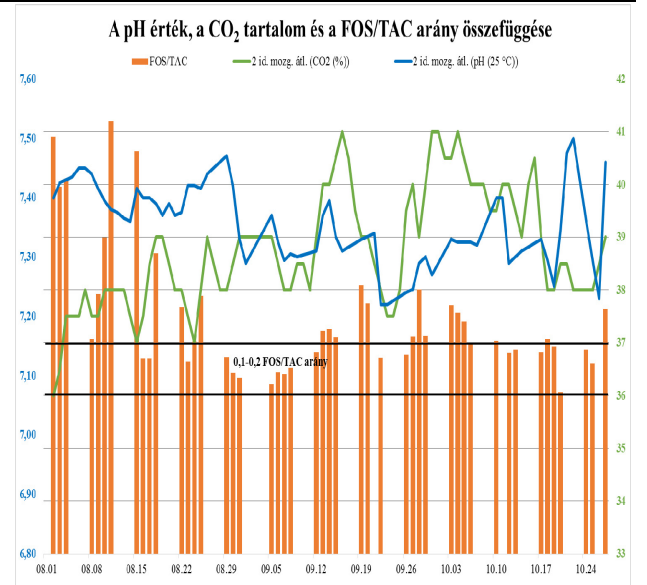

1. ábra. $A p H$, a szén-dioxid tartalom és a FOS/TAC összefüggése

A szén-dioxid akkor volt alacsony, amikor a FOS/TAC arány magasabb értékeket mutatott. A 0,1 körüli FOS/TAC aránynál már emelkedni kezdett a szén-dioxid menynyisége, amely azt tükrözi, hogy a biogáz rosszabb minőségü lett. Nagyon szépen látszik ennek eredménye például szeptemberben, de az egész időszakban megfigyelhető ez a jelenség. A pH értéket befolyásoló hatásösszefüggés nem mutatkozik ebben a grafikonban. Leginkább állandóság (valamint minimális változás) figyelhető meg, mely elsősorban a kedvező puffer-hatásnak lehet a következménye. A diagram adatai alapján tehát az üzemben átlagosan enyhén lúgos $\mathrm{pH}$ és alacsony FOS/TAC érték jellemző. Ezáltal megállapítható, hogy a debreceni szennyvíztisztító telep esetén a kapott értékek alapján, a 0,1 körüli FOS/TAC arány nem tekinthető optimálisnak, mely valóban alulterheltséget jelez a technológiai folyamatban.

\subsection{A biogáz hozam adatok és a FOS/TAC érték kapcsolata}

A szakirodalom által megfogalmazott optimális FOS/TAC arányszám a gyakorlatban 0,3 és 0,4 közötti tartományban helyezkedik el [4]. A kutatás során a biogáz 
hozam és a FOS/TAC értékek összefüggéseit a 2. ábrán látható eredmények mutatják. A pontdiagramon jól látszódik, hogy összesen két értéket tudtunk detektálni a 0,3-0,4 közötti tartományban.

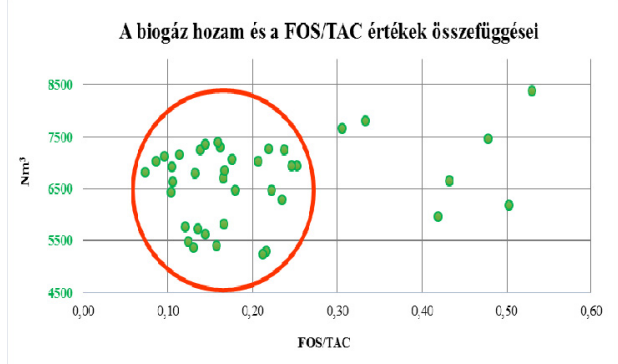

2. ábra. $A$ biogáz hozam és a hozzá tartozó FOS/TAC arányok

A biogáz hozam és a FOS/TAC arány összefüggésénél látható piros körrel azt szeretnénk hangsúlyozni, hogy a legtöbb zöld pont jóval az optimális tartomány alatt 0,08 és 0,25 érték között helyezkedik el. Az optimális tartomány alatt lévők esetén elmondható, hogy a kutatási időszak ezen szakaszában csak telepi szennyvíziszap volt felvezetve a rothasztókra, ezáltal arra lehet következtetni, hogy a meglévő rothasztó rendszer a három rothasztó torony össztérfogatával nagyobb szerves anyag mennyiséget igényelne az optimális 0,3-0,4 közötti FOS/TAC arány eléréséhez.

\section{Következtetések}

A szennyvíztisztító telepen végzett laboratóriumi vizsgálatok során a szakirodalmi adatoknál alacsonyabb 0,1 körüli FOS/TAC arányok és a detektált üzemeltetési ellenőrző paraméterek értékei a telep alulterheltségére utalnak.

Megoldás lehet ebben a helyzetben a terhelés növelése, ami történhet külső forrásból történő szerves anyag adagolással vagy a rothasztó térfogat csökkentésével, leállításával. Lehetőség van továbbá a telepen képződő iszapmennyiség további 10\%kal történő növelésére más szennyvíztelepekről származó iszap fogadásával.

A vizsgálati időszak eredményeinek elemzése alapján tehát a FOS/TAC érték segíthet az esetleges stressz faktorok kiszürésében. Javasolom további folyamatos vizsgálatát a telepen az összefüggések pontosabb feltárása érdekében.

\section{Szakirodalmi hivatkozások}

[1] D. Fytili, A. Zabaniotou (2008): Utilization of sewage sludge in EU application of old and new methods - A review. Renewable and Sustainable Energy Reviews, 12. 116-140.

[2] Tchobanoglous G., Burton F. L., Stensel H. D. (2003): Wastewater Engineering. Treatment and reuse. 4th edition. Metcalf \& Eddy Inc. McGraw Hill Science. 986-996.

[3] Juhász E. (2011): A szennyviztisztitás története, Magyar Víziközmü Szövetség, Budapest, 184.

[4] Öllős G., Oláh J., Palkó Gy. (2010): Rothasztás, Magyar Víziközmü Szövetség, Budapest, 320.

[5] Kárpáti Á. (2002): Szennyviziszap rothasztás és komposztálás, Ismeretgyüjtemény 6 . Veszprémi Egyetem Környezetmérnöki és Kémiai Technológia Tanszék, Veszprém, 104.

[6] Nordmann, W. (1977). Die Überwachung der Schlammfaulung. KA-Informationen für das Betriebspersonal, Beilage zur Korrespondenz Abwasser 3.77.

[7] Pfeifer, B. (2007). Meßgerät FOS/TAC 2000 - Messeneuheit von der Agritechnica.

(Pronova Analysentechnik, Novatech GmbH., Energie Pflanzen. VI/2007. 53.

[8] Voß, E., Weichgrebe D., Rosenwinkel, K.H. (2009). FOS/TAC - Deduction, Methods, Application and Significance. Internationale Wissenschaftskonferenz „Biogas Science 2009 - science meets practice", LfL-Bayern, 2-4. 12.09. Erding. 